Research Article

\title{
Seasonal Diversity of Lactic Acid Bacteria in Artisanal Yoghurt and Their Antibiotic Susceptibility Pattern
}

\author{
Lamye Glory Moh $\mathbb{D}^{1,2}$ Pamo Tedonkeng Etienne, ${ }^{3}$ and Kuiate Jules-Roger $\mathbb{D}^{1}$ \\ ${ }^{1}$ Department of Biochemistry, Faculty of Science, University of Dschang, P.O. Box 67, Dschang, Cameroon \\ ${ }^{2}$ Department of Microbiology, Faculty of Science, University of Yaounde 1, Yaounde, Cameroon \\ ${ }^{3}$ Department of Animal Production, Faculty of Agronomy and Agricultural Science, University of Dschang, Dschang, Cameroon
}

Correspondence should be addressed to Kuiate Jules-Roger; jrkuiate@yahoo.com

Received 10 December 2020; Revised 26 January 2021; Accepted 2 February 2021; Published 12 February 2021

Academic Editor: Ahmed Al-Alawi

Copyright (c) 2021 Lamye Glory Moh et al. This is an open access article distributed under the Creative Commons Attribution License, which permits unrestricted use, distribution, and reproduction in any medium, provided the original work is properly cited.

\begin{abstract}
The microbiological quality of artisanal yoghurt marketed in some regions of Cameroon was evaluated during the dry and rainy seasons alongside three commercial brands and the susceptibility of isolates to some conventional antibiotics. A total of ninetysix (96) samples were collected, and the microbiological quality was based on the total count of lactic acid bacteria (lactobacilli and cocci) as well as the identification of species present using identification kits. The susceptibility of isolates was determined using the microdilution method. The lactobacillus counts of locally made yoghurts during both seasons were lower than those of the commercial samples. However, there was a general reduction of viable count of lactobacilli within the samples during the rainy season when compared to the dry season while a general increase in the total coccus count was observed during the rainy season except samples from Bamenda which instead decreased. Five (5) Lactobacillus species belonging to one genera were identified from 29 lactobacillus isolates. Lactobacillus bulgaricus was the highest (64.28\%), present in 71.42\%, 50.00\%, 33.33\%, and $33.33 \%$ (dry season) compared to $85.71 \%, 100 \%, 33.33 \%$, and $25.00 \%$ (rainy season) from Bamenda, Dschang, Bafoussam, and commercial, respectively. More so, 14 cocci, 3 coccobacilli, and 1 rod species belonging to 5, 3, and 1 genera were identified, from 74 cocci, 12 coccobacilli, and 3 rod isolates, respectively, with Streptococcus thermophilus being the highest (35.55\%). However, $93.33 \%$ of the lactobacillus isolates were very sensitive to the antibiotics used, while only $20 \%$ of cocci were sensitive. This result suggests that the paucity of the appropriate lactic acid bacteria (LAB) and presence of pathogenic LAB caused by the absence of quality control and ignorance might hinder its health benefits and protection offered to consumers with a resultant exposure to high risk of food borne infection and intoxication coupled to the resistant strains.
\end{abstract}

\section{Introduction}

Yoghurt is a coagulated milk product resulting from the fermentation of lactose in milk by lactic acid bacteria (LAB) (Lactobacillus delbrueckii subsp. bulgaricus and Streptococcus salivarius subsp. thermophilus) to liberate lactic acid which is responsible for its unique taste $[1,2]$. LAB comprises a heterogeneous group of gram positive bacteria, acid tolerant, generally nonsporulating, nonrespiring rods, or cocci grouped together based on their common metabolic and physiological characteristics [3]. There are about 20 genera within the phylum Firmicutes, and the genera Aerococcus, Carnobacterium, Enterococcus, Lactobacillus, Lactococcus,
Leuconostoc, Oenococcus, Pediococcus, Streptococcus, Tetragenococcus, Vagococcus, and Weissella have been considered as the principal LAB $[4,5]$. Some of these genera (Lactococcus and Lactobacillus) are considered safe while members of the genera Streptococcus and Enterococcus have been known to contain some opportunistic pathogens [6]. These bacteria are widely found in nature, including the gastrointestinal and urogenital tracts of humans [7, 8] and animals [7], environments rich in carbohydrates, decomposing plants, and fermented foods such as cheeses and yoghurts.

Lactic acid, produced by LAB during fermentation, as the major metabolic end product together with other antimicrobial substances, inhibits the growth of unwanted 
microorganisms $[9,10]$. This inhibition increases yoghurt nutritive and sanitary qualities and shelf life, while reducing the risk of food borne diseases $[11,12]$. However, the presence of pathogens and spoilage microorganisms in yoghurt without the minimum viable $\mathrm{LAB}$ count makes it unsafe to the consumers despite its nutritional composition [13, 14]. Since yoghurt is mostly consumed because of the increasing search for healthy foods, it is very important for it to provide the required health benefits to its consumers $[15,16]$.

Some LAB present in yoghurt may be resistant to conventional antibiotics, constituting a serious health problem because the pathogenic ones may cause infections in people that may be difficult to be eradicated $[17,18]$. According to World Health Organization [17], the rate of emergence of antimicrobial resistance has increased because of improper autoprescription of antibacterial substances. During the recent decades, there has been concern about the possibility of antibiotic resistance spreading in the environment [18]. Therefore, looking for resistant microorganisms in food is essential to ensure food safety, create awareness among common people (producers and consumers), and to protect the health and rights of consumers.

It is generally accepted that yoghurt should contain a minimum of $10^{7} \mathrm{cfu} / \mathrm{ml}$ of viable bacteria during consumption [19]. This is not always the case as some have been known to either have bacterial count above or equal [20, $21]$ or below $[22,23]$ the recommended dose. More so, when culture or previous day yoghurt used in the fermentation of yoghurt is undefined and used in improper ratio and amount, like the case of artisanal yoghurt, it may contain mixtures of various desirable and undesirable strains of LAB bacteria. As such, the quality of yoghurts may vary with the type of starter culture used [24, 25]. However, having the recommended dose without species identification can be misleading because it is very important to know the exact species present in these yoghurts. In Cameroon, artisanal yoghurts are produced during the rainy and dry seasons and most producers do abandon production during the former season because of cold weather, low consumption, longer fermentation time, and/or difficulties during yoghurt fermentation [14]. This yoghurt is cheaper than the commercial types which in turn are preferred by consumers who have little or no knowledge of its quality [13]. These locally made yoghurts are often prepared without any care of quality control and hygienic conditions due to negligence and ignorance by producers and the competent authorities. More so, they are prepared by these producers using different means and methods without an idea of the advantages and disadvantages of each method. All these, together with seasonal changes, enabled us to conceive this work, which is aimed at comparing the microbiological quality of different yoghurts (artisanal and commercial) produced in some towns of Cameroon in terms of LAB enumeration and species present during the dry and rainy seasons, as well as their susceptibility to some conventional antibiotics.

\section{Materials and Methods}

2.1. Collection of Samples. Samples of locally made yoghurts were collected from 15 (dry seasons) and 14 (rainy seasons) producers in duplicate at three different occasions from some towns (Bamenda, Bafoussam, and Dschang) of Cameroon. This gave a total of eighty-seven (87) samples, forty-five (45) and forty-two (42) during the dry (November-January) and rainy (May-early August) seasons, respectively. Concurrently, there are three (3) commercial brands of yoghurt: (BB), (AA), and (CC) available in Cameroon were equally collected on the same day from a well-known sale point in Dschang, giving an overall sample size of ninety-six (96). Samples were collected in sterile and labeled containers and transported under aseptic conditions in an ice-packed cooler, at $4-7^{\circ} \mathrm{C}$ to the Research Unit of Microbiology and Antimicrobial Substances (RUMAS), Faculty of Science, University of Dschang.

\subsection{Microbiological Analysis}

2.2.1. Preparation of Materials. All media were obtained in dehydrated forms and prepared according to the manufacturer's instructions. Glass wares such as Petri dishes, test tubes, pipettes, flasks, and bottles were sterilized in a hot oven at $170^{\circ} \mathrm{C}$ for two hours [26].

2.2.2. Preparation of Serial Dilutions. This was done according to A.P.H.A, [27] during which one milliliter $(1 \mathrm{ml})$ of yoghurt from a homogenous sample was ten folds serially diluted into $9 \mathrm{ml}$ of sterile distilled water to obtain a series of eight dilutions ranging from $10^{-1}$ to $10^{-8}$. Fifty microliters $(50 \mu \mathrm{l})$ of diluted samples were spread over prepared dried plates with different media.

2.2.3. Enumeration of Lactic Streptococci and Other Cocci. M17 agar (Qingdao-China) was used to enumerate Streptococcus sp. and other cocci in yoghurt samples and incubated aerobically at $37^{\circ} \mathrm{C}$ for 48 hours according to Torriani et al. [28].

2.2.4. Enumeration of Lactobacilli. MRS Rogosa agar (Micromaster Laboratories Pvt. Ltd, Maharashtra-India) was used for enumeration of lactobacilli according to Tharmaraji and Shah [29]. Plates were incubated under microaerophilic condition at $37^{\circ} \mathrm{C}$ for 48 hours.

Colonies from the cultured plates were differentiated and purified using the streak method. Purified colonies were prepared in their respective broth, MRS broth (Micromaster Laboratories Pvt. Ltd, Maharashtra-India) for lactobacilli and M-17 broth (Qingdao-China) for cocci.

2.3. Identification of Lactic Acid Bacteria. Gram positive and catalase negative bacteria were examined microscopically (cell morphology and arrangements). The rods and coccus bacteria were presumptively identified as LAB according to Gerhartdt et al. [30]. The ability to ferment carbohydrate substrates was studied using the API $50 \mathrm{CH}$ galleries and API 50 CHL medium(lactobacilli), and API 20 Strep (cocci) (BioMerieux, Marcy l'Etoile, France) system, which enabled the identification of LAB isolates to species level. All tests were performed according to the manufacturer's instructions. The API LAB PLUS database (BioMerieux, SA) and 
accompanying computer software were used to interpret the result obtained.

\subsection{The Susceptibility of Isolates (LAB) to Conventional Antibiotics}

2.4.1. Chemicals for Susceptibility Testing. Tetracycline (TET), ciprofloxacin (CIP), chloramphenicol (CHL), ampicillin (AMP), streptomycin (STR), gentamycin (GEN), erythromycin (ERY), and norfloxacin (NOR) (Sigma-Aldrich, St Quentin Fallavier, France) were used as reference antibiotics (RA). $\rho$-Iodonitrotetrazolium chloride (INT, Sigma-Aldrich) was used as a microbial growth indicator $[31,32]$. The antibiotics used in this study were selected on the basis of their mechanisms of action, targeting different sites or processes although duplicates were included in some cases.

2.4.2. Microbial Strains and Culture Media. All microorganisms were obtained from the yoghurt samples used in this study. MRS agar (for lactobacilli) and M-17 agar (lactic streptococci and other cocci) were used to activate the tested LAB isolates. The minimum inhibitory concentration (MIC) and minimum microbicidal concentration (MBC) determinations on the tested bacteria were conducted using rapid INT colorimetric assay.

2.4.3. Determination of MIC and MBC by INT Colorimetric Assay. The MICs were obtained by using the rapid INT colorimetric assay according to described methods [31] with some modifications [33]. The antibiotics were dissolved in dimethylsufoxide (DMSO) solution, introduced into the first wells of the microtitre plates and serially diluted two folds with Mueller Hinton Broth (MHB) to a final volume of $100 \mu \mathrm{l}$. One hundred microliters $(100 \mu \mathrm{l})$ of inoculum $1.5 \times$ $10^{6} \mathrm{cfu} / \mathrm{ml}$ prepared in the broth was added [33]. The plates were covered with a sterile plate sealer and incubated at $37^{\circ} \mathrm{C}$ for $18 \mathrm{~h}$. The MICs of samples were detected following addition of INT $(40 \mu \mathrm{l}$ of $0.2 \mathrm{mg} / \mathrm{ml})$ and incubation at $37^{\circ} \mathrm{C}$ for $30 \mathrm{~min}$. Viable bacteria reduced the yellow dye to pink. MIC was defined as the lowest sample concentration that prevented the color change of the medium and exhibited complete inhibition of microbial growth [31]. MBCs were determined by adding $50 \mu \mathrm{l}$ aliquots of the preparations, which did not show any growth after incubation and which did not receive INT, to $150 \mu \mathrm{l}$ of broth. These preparations were incubated at $37^{\circ} \mathrm{C}$ for $48 \mathrm{~h}$. The $\mathrm{MBC}$ was regarded as the lowest concentration of antibiotic, which did not produce a color change after addition of INT as mentioned above [33]. The final concentration of DMSO was lower than $2.5 \%$ and has been known not to affect the microbial growth [34]. The assays were performed in triplicate and repeated thrice.

2.5. Statistical Analysis. Analyzable data were subjected to the one-way analysis of variance (ANOVA), and differences between samples at $p \leq 0.05$ were determined by WallerDuncan test using the Statistical Package for the Social Sciences (SPSS) version 11.0. The results were expressed (where appropriate) as mean \pm standard deviation of the replicates.

\section{Results and Discussion}

\subsection{Lactic Acid Bacteria Count}

3.1.1. Lactobacillus Count. Samples PA, MR, and MB (Bamenda), P (Dschang), K (Bafoussam), and BB (commercial 2) were completely void of lactobacilli during the dry and rainy season (except MB) as shown in Table 1. Just as during the dry season, lactobacillus counts of all artisanal yoghurt samples were not significantly different $(p>0.05)$ from those of the commercial samples, and within the samples, there was a general reduction of viable count during the rainy season when compared to the dry season (Table 1). Within the samples (commercial and artisanal), the reduction in colony counts was generally 10 folds, and most of the yoghurt samples had very low counts of lactobacilli. The low count observed during the rainy season could probably be due to the fact that Lactobacillus bulgaricus needs a particular temperature for proper growth. Temperatures below or above will lead to failure, and as such, temperature fluctuations during this season might negatively affect the survival of these microorganisms.

3.1.2. Coccus Count. The total coccus count of $66.66 \%, 50 \%$, $50 \%$, and $0 \%$ of samples from Dschang, Bamenda, Bafoussam, and commercial, respectively, did not vary significantly $(p>0.05)$ among themselves during the dry season (Table 1$)$. Generally, there was no significant difference $(p>0.05)$ between the locally made or artisanal yoghurts and the commercial yoghurt samples except for samples from Bamenda which were significantly lower $(p<0.05)$. More so, samples from Dschang and Bafoussam were significantly higher $(p<0.05)$ than the commercials during the rainy season (Table 1). Fifty percent (50\%) and thirty percent (30\%) of the artisanal yoghurts had coccus counts significantly lower than those of the commercial samples during the rainy and dry seasons, respectively. There was a general increase in the total coccus count during the rainy season when compared to those obtain during the dry season (Table 1) with the exception of samples from Bamenda which did not vary significantly $(p>0.05)$. Summarily, samples from Bamenda had the lowest coccus counts during both seasons. During the rainy season, the turnover of yoghurt is lower because of ignorance; a good number of people consume it just to quench taste; as such, there is little or limited consumption during this season. This could lead to a longer selling/storage time, and hence, temperature fluctuations caused by daily movement to and from the market, thus a favorable environment for the cocci to multiply.

Yoghurt should contain $10^{7}$ viable cells of LAB (lactobacilli and cocci) per milliliter in the finished product in order to produce the desired health benefits $[1,35]$. This standard was met in $26.67 \%$ and $35.71 \%$ of all the samples collected during the dry and rainy seasons, respectively, while it was $0 \%$ and $33.33 \%$ for commercial samples collected during the two seasons, respectively. Variations in total viable bacterial counts (lactobacilli and cocci) among artisanal yoghurt samples might be due to the use of left-over artisanal and/or commercial yoghurt for fermentation in 
TABLE 1: Lactic acid bacteria counts of yoghurt during the dry and rainy seasons as a function of place of production and sample.

\begin{tabular}{|c|c|c|c|c|c|}
\hline \multirow{3}{*}{ Location } & \multirow{3}{*}{ Samples } & \multicolumn{4}{|c|}{ Lactic acid bacteria colony counts $(\log 10 \mathrm{cfu} / \mathrm{ml})$} \\
\hline & & \multicolumn{2}{|c|}{ Dry season } & \multicolumn{2}{|c|}{ Rainy season } \\
\hline & & Lactobacillus counts & Coccus counts & Lactobacillus counts & Coccus counts \\
\hline Dschang & $\mathrm{V}$ & $3.46 \pm 0.24^{\mathrm{c}}$ & $5.24 \pm 0.18^{\mathrm{d}}$ & / & 1 \\
\hline Dschang & $\mathrm{P}$ & $0.00 \pm 0.00^{\mathrm{a}}$ & $7.30 \pm 0.05^{\mathrm{h}}$ & $0.00 \pm 0.00^{\mathrm{a}}$ & $9.70 \pm 0.04^{1}$ \\
\hline \multirow[t]{2}{*}{ Dschang } & G & $4.75 \pm 0.05^{\mathrm{g}}$ & $5.31 \pm 0.02^{\mathrm{d}}$ & $3.98 \pm 0.07^{\mathrm{ef}}$ & $6.26 \pm 0.04^{\mathrm{h}}$ \\
\hline & Mean & $2.74 \pm 2.13^{\alpha}$ & $5.95 \pm 1.01^{\beta}$ & $1.99 \pm 2.18^{\alpha}$ & $7.98 \pm 1.88^{\gamma}$ \\
\hline Bamenda & NR & $4.09 \pm 0.01^{\mathrm{f}}$ & $4.70 \pm 0.19^{\mathrm{b}}$ & $3.02 \pm 0.21^{\mathrm{cd}}$ & $3.48 \pm 0.12^{\mathrm{b}}$ \\
\hline Bamenda & $S$ & $2.94 \pm 0.18^{\mathrm{b}}$ & $4.36 \pm 0.12^{\mathrm{a}}$ & $4.15 \pm 0.13^{\mathrm{ef}}$ & $3.83 \pm 0.04 c$ \\
\hline Bamenda & $\mathrm{D}$ & $3.85 \pm 0.05^{\mathrm{e}}$ & $4.78 \pm 0.02^{\mathrm{bc}}$ & $4.18 \pm 0.07^{\mathrm{ef}}$ & $4.06 \pm 0.03^{\mathrm{d}}$ \\
\hline Bamenda & MR & $0.00 \pm 0.00^{\mathrm{a}}$ & $5.58 \pm 0.01^{\mathrm{e}}$ & $0.00 \pm 0.00^{\mathrm{a}}$ & $3.11 \pm 0.28^{\mathrm{a}}$ \\
\hline Bamenda & $\mathrm{MB}$ & $0.00 \pm 0.00^{\mathrm{a}}$ & $4.30 \pm 0.34^{\mathrm{a}}$ & $3.61 \pm 0.07^{\mathrm{de}}$ & $4.01 \pm 0.02^{\mathrm{d}}$ \\
\hline Bamenda & $\mathrm{PA}$ & $0.00 \pm 0.00^{\mathrm{a}}$ & $7.33 \pm 0.09^{h}$ & $0.00 \pm 0.00^{\mathrm{a}}$ & $5.86 \pm 0.03^{\mathrm{g}}$ \\
\hline Bamenda & SY & $4.74 \pm 0.03^{\mathrm{g}}$ & $4.25 \pm 0.03^{\mathrm{a}}$ & $4.08 \pm 0.09^{\mathrm{ef}}$ & $4.24 \pm 0.04^{\mathrm{e}}$ \\
\hline \multirow[t]{2}{*}{ Bamenda } & PV & $3.89 \pm 0.01^{\mathrm{e}}$ & $4.30 \pm 0.34^{\mathrm{a}}$ & $3.18 \pm 0.06^{\mathrm{cd}}$ & $4.01 \pm 0.02^{\mathrm{d}}$ \\
\hline & Mean & $2.44 \pm 1.98^{\alpha}$ & $4.95 \pm 1.02^{\alpha}$ & $2.78 \pm 1.69^{\alpha}$ & $4.07 \pm 0.77^{\alpha}$ \\
\hline Bafoussam & $\mathrm{T}$ & $4.07 \pm 0.15^{\mathrm{f}}$ & $5.32 \pm 0.04^{\mathrm{d}}$ & $3.76 \pm 0.12^{\mathrm{de}}$ & $8.67 \pm 0.06^{\mathrm{k}}$ \\
\hline Bafoussam & $\mathrm{Ce}$ & $3.67 \pm 0.09^{\mathrm{d}}$ & $5.24 \pm 0.18^{\mathrm{d}}$ & $2.60 \pm 0.30^{c}$ & $9.71 \pm 0.04^{1 \mathrm{~m}}$ \\
\hline Bafoussam & $\mathrm{C}$ & $5.14 \pm 0.04^{\mathrm{h}}$ & $7.72 \pm 0.02^{\mathrm{i}}$ & $1.79 \pm 1.55^{\mathrm{b}}$ & $9.84 \pm 0.03^{\mathrm{m}}$ \\
\hline \multirow[t]{2}{*}{ Bafoussam } & $\mathrm{K}$ & $0.00 \pm 0.00^{\mathrm{a}}$ & $7.76 \pm 0.02^{\mathrm{i}}$ & $0.00 \pm 0.00^{\mathrm{a}}$ & $9.68 \pm 0.05^{1}$ \\
\hline & Mean & $3.22 \pm 2.02^{\alpha}$ & $6.51 \pm 1.28^{\beta}$ & $2.04 \pm 1.58^{\alpha}$ & $9.47 \pm 0.49^{\delta}$ \\
\hline Commercial 1 & $\mathrm{AA}$ & $5.19 \pm 0.08^{h i}$ & $6.20 \pm 0.01^{\mathrm{f}}$ & $4.58 \pm 0.08^{\mathrm{f}}$ & $5.13 \pm 0.19^{\mathrm{f}}$ \\
\hline Commercial 2 & $\mathrm{BB}$ & $0.00 \pm 0.00^{\mathrm{a}}$ & $6.74 \pm 0.03^{\mathrm{g}}$ & $0.00 \pm 0.00^{\mathrm{a}}$ & $7.78 \pm 0.01^{j}$ \\
\hline \multirow[t]{2}{*}{ Commercial 3} & CC & $5.31 \pm 0.10^{\mathrm{i}}$ & $4.94 \pm 0.04^{\mathrm{c}}$ & $4.25 \pm 0.15^{\mathrm{ef}}$ & $6.82 \pm 0.03^{\mathrm{i}}$ \\
\hline & Mean & $3.50 \pm 2.62^{\alpha}$ & $5.96 \pm 0.79^{\beta}$ & $2.94 \pm 2.21^{\alpha}$ & $6.58 \pm 1.16^{\beta}$ \\
\hline
\end{tabular}

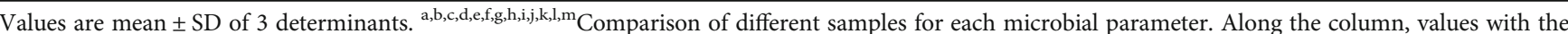
same letter are not significantly different $(p>0.05) .{ }^{\alpha, \beta, \gamma, \delta}$ Comparison of mean of all samples from different places and seasons, mean with the same Greek alphabet are not significantly different $(p>0.05)$; /: absence of producer.

improper ratio and amount which contains heterogeneous mixture of LAB coupled to the absence of quality control. Variations may also be caused by temperature fluctuations as a result of unstable electricity supply. This variation was also observed by Masud et al. [24].

\subsection{Lactic Acid Bacteria Species}

3.2.1. Lactobacillus Species. Twenty-nine (29) lactobacillus isolates obtained from ninety-six (96) yoghurt samples were identified to species level with 13 and 15 isolates during the dry (D.S) and rainy (R.S) seasons, respectively (Table 2). These isolates were further distributed as follows: 12 (5 D.S and 7 R.S), 3 (2 D.S and 1 R.S), 6 (3 D.S and 3 R.S), and 7 (3 D.S and 4 R.S) from Bamenda, Dschang, Bafoussam, and commercial, respectively. Five (5) Lactobacillus species belonging to one genera were identified, with the number of occurrences indicated in parentheses: Lactobacillus bulgaricus (18), Lactobacillus viridescens (2), Lactobacillus fermentum (4), Lactobacillus lactis (2), and Lactobacillus cellobiosus (3) (Table 3).

It was noticed that although these samples had lactobacilli as shown by colony count on MRS agar, it was revealed after identification that $30.77 \%$ of samples had lactobacilli entirely different from $L$. bulgaricus. The other samples had either L. bulgaricus or mixed with other lactobacilli (Table 2). Among the samples that had lactobacilli, 83.33\%, $50 \%, 33.33 \%$, and 50\% from Bamenda, Dschang, Bafoussam, and commercials had L. bulgaricus, respectively (Table 2). Out of 17 yoghurt samples, 13 had Lactobacillus sp. with $L$. bulgaricus found in 9 and $L$. viridescens and L. fermentum in 2; meanwhile, L. lactis and L. cellobiosus were found in just one each. From the 29 isolates, L. bulgaricus was the highest (64.28\%), present in $71.42 \%, 50.00 \%, 33.33 \%$, and $33.33 \%$ (dry season) compared to $85.71 \%, 100 \%, 33.33 \%$, and $25.00 \%$ (rainy season) from Bamenda, Dschang, Bafoussam, and commercial, respectively. This was followed by L. fermentum (14.28\%), absent in samples from Bamenda, Dschang, and commercial but representing $66.67 \%$ of isolates from Bafoussam during both seasons. The rest had the following percentages: L. cellobiosus (10.71\%), L. lactis, and L. viridescens $(7.14 \%)$ as shown in Table 2.

L. fermentum, L. lactis, and L. cellobiosus were mostly found in the commercial yoghurts except L. fermentum which was present in some yoghurt samples from Bafoussam. Although some may be useful, their presence in yoghurt could be accidental. They surely entered into these yoghurts as contaminants. L. fermentum is a heterofermentative LAB, when allowed to grow in significant numbers in yoghurt can cause defects such as bloated packaging because 
TABLE 2: Lactobacillus species found in yoghurt samples during the dry and rainy season.

\begin{tabular}{|c|c|c|c|}
\hline \multirow{2}{*}{ Place } & \multirow{2}{*}{ Name of isolate } & \multicolumn{2}{|c|}{ Producers } \\
\hline & & Dry season & Rainy season \\
\hline \multirow{2}{*}{ Bamenda } & Lactobacillus bulgaricus & $\mathrm{NR}, \mathrm{D}, \mathrm{PV}, \mathrm{S}, \mathrm{SY}$ & $\mathrm{NR}, \mathrm{D}, \mathrm{PV}, \mathrm{S}, \mathrm{MB}, \mathrm{SY}$ \\
\hline & Lactobacillus viridescens & 1 & $\mathrm{D}$ \\
\hline \multirow{2}{*}{ Dschang } & Lactobacillus bulgaricus & G & G \\
\hline & Lactobacillus viridescens & $\mathrm{V}$ & 1 \\
\hline \multirow{2}{*}{ Bafoussam } & Lactobacillus bulgaricus & $\mathrm{T}$ & $\mathrm{T}$ \\
\hline & Lactobacillus fermentum & $\mathrm{Ce}, \mathrm{C}$ & $\mathrm{Ce}, \mathrm{C}$ \\
\hline \multirow{3}{*}{ Commercials } & Lactobacillus bulgaricus & $\mathrm{AA}$ & AA \\
\hline & Lactobacillus lactis & $\mathrm{AA}$ & $\mathrm{AA}$ \\
\hline & Lactobacillus cellobiosus & $\mathrm{CC}$ & $\mathrm{CC}$ \\
\hline
\end{tabular}

/: absence of lactobacilli.

TABLE 3: The distribution of lactobacillus species as a function of place.

\begin{tabular}{|c|c|c|c|c|c|c|c|c|c|c|c|c|}
\hline \multirow{3}{*}{$\begin{array}{l}\text { Lactobacilli } \\
\text { isolated } \\
\text { from yoghurt }\end{array}$} & \multicolumn{8}{|c|}{ Yoghurt samples/season } & \multirow{3}{*}{$\begin{array}{c}\text { Frequency of } \\
\text { occurrence } \\
\text { Dry } \\
\text { season }\end{array}$} & \multirow{3}{*}{$\begin{array}{c}\% \text { of } \\
\text { occurrence } \\
\text { Dry } \\
\text { season }\end{array}$} & \multirow{3}{*}{$\begin{array}{c}\text { Frequency of } \\
\text { occurrence } \\
\text { Rainy } \\
\text { season }\end{array}$} & \multirow{3}{*}{$\begin{array}{c}\% \text { of } \\
\text { occurrence } \\
\text { Rainy } \\
\text { season }\end{array}$} \\
\hline & \multicolumn{2}{|c|}{ Bamenda } & \multicolumn{2}{|c|}{ Dschang } & \multicolumn{2}{|c|}{ Bafoussam } & \multicolumn{2}{|c|}{ Commercial } & & & & \\
\hline & $\begin{array}{c}\text { Dry } \\
\text { season }\end{array}$ & $\begin{array}{l}\text { Rainy } \\
\text { season }\end{array}$ & $\begin{array}{c}\text { Dry } \\
\text { season }\end{array}$ & $\begin{array}{l}\text { Rainy } \\
\text { season }\end{array}$ & $\begin{array}{c}\text { Dry } \\
\text { season }\end{array}$ & $\begin{array}{l}\text { Rainy } \\
\text { season }\end{array}$ & $\begin{array}{c}\text { Dry } \\
\text { season }\end{array}$ & $\begin{array}{l}\text { Rainy } \\
\text { season }\end{array}$ & & & & \\
\hline $\begin{array}{l}\text { Lactobacillus } \\
\text { bulgaricus }\end{array}$ & + & + & + & + & + & - & + & + & 4 & 100 & 3 & 75 \\
\hline $\begin{array}{l}\text { Lactobacillus } \\
\text { viridescens }\end{array}$ & + & - & - & + & - & - & - & - & 1 & 25 & 1 & 25 \\
\hline $\begin{array}{l}\text { Lactobacillus } \\
\text { fermentum }\end{array}$ & - & - & - & - & - & + & - & - & 0 & 00 & 1 & 25 \\
\hline $\begin{array}{l}\text { Lactobacillus } \\
\text { lactis }\end{array}$ & - & - & - & - & - & - & + & + & 1 & 25 & 1 & 25 \\
\hline $\begin{array}{l}\text { Lactobacillus } \\
\text { cellobiosus }\end{array}$ & - & - & - & - & - & - & + & + & 1 & 25 & 1 & 25 \\
\hline
\end{tabular}

+: positive; -: negative.

of the production of other acids and $\mathrm{CO}_{2}$. L. cellobiosus is a biotype of $L$. fermentum since they are closely related [36]. Meanwhile, L. viridescens is an ubiquitous organism found in meat, plants, and meat products $[37,38]$ associated with discolorations [39] and might have entered into yoghurt samples through unhygienic practices during production. It is also considered a potent spoilage organism, as shelf life is reduced due to deterioration caused by this pathogen.

3.2.2. Cocci, Coccobacilli, and Rod Species. Seventy-four (74) cocci, 12 coccobacilli, and 3 rods from ninety-six (96) yoghurt samples were identified to species level (Table 4). The isolates were distributed as follows: cocci (33 (16 D.S and 17 R.S)), 11 (6 D.S and 5 R.S), 17 (9 D.S and 8 R.S), and 13 (6 D.S and 7 R.S); coccobacilli (11 (6 D.S and 5 R.S)), 1 (1 D.S and 0 R.S), 0 , and 0; rods (2 (1 D.S and 1 R.S)), 1 (0 D.S and 1 R.S), 0, and 0 from Bamenda, Dschang, Bafoussam, and commercial, respectively. Fourteen (14) cocci, 3 coccobacilli, and 1 rod species belonging to 5, 3, and 1 genera were identified, respectively, with the number of occurrences indicated in parentheses: Streptococcus thermophilus (32), Streptococcus constellatus (2), Streptococcus canis (1), Streptococcus acidomonimus (4), Streptococcus uberis (1), Streptococcus bovis 1 (1), Enterococcus faecium
(3), Enterococcus durans (6), Enterococcus avium (3), Aerococcus viridans 1 (10), Aerococcus viridans 2 (8), Aerococcus viridans 3 (1), Lactococcus lactis subsp. lactis (2), Leuconostoc sp. (coccobacilli) (10), Listeria sp. (rod) (3), Abiotrophia defectiva (coccobacilli) (1), Gardnerella vaginalis (coccobacilli) (1), and Gemella haemolysans (1) (Table 5).

Besides S. thermophilus, so many other cocci and even coccobacilli and rods of which some can cause diseases in humans were isolated, indicating a high level of bad production practices. The season or time of the year had no effect on S. thermophilus, which was the highest represented isolate (35.55\%), present in $76.47 \%$ of samples. All samples from Bamenda and Dschang had S. thermophilus, but only $50 \%$ and $33.33 \%$ of samples from Bafoussam and commercial brands, respectively, had it. This was followed by A. viridans (21.11\%), present in $22.22 \%$ of samples during the dry and rainy seasons. A. viridans occupied $31.81 \%, 25 \%, 11.11 \%$, and $16.67 \%$ (dry season) as well as $29.16 \%, 0.00 \%, 25 \%$, and $14.28 \%$ (rainy season) from Bamenda, Dschang, Bafoussam, and commercial, respectively (Table 4). Apart from that, enterococci (Enterococcus faecium, Enterococcus durans, and Enterococcus avium) was the third abundant isolate (13.33\%) with $0.00 \%, 12.5 \%, 22.22 \%$, and $50 \%$ (dry season) as well as $4.17 \%, 16.67 \%, 12.50 \%$, and $42.86 \%$ (rainy season) 
TABLE 4: Cocci, coccobacilli, and rod species found in yoghurt samples during the rainy and dry season.

\begin{tabular}{|c|c|c|c|}
\hline \multirow{2}{*}{ Place } & \multirow{2}{*}{ Name of isolate } & \multicolumn{2}{|c|}{ Producers } \\
\hline & & Dry season & Rainy season \\
\hline \multirow{10}{*}{ Bamenda } & Streptococcus thermophilus & NR, MR, PV, SY, D, S, MB & NR, MR, PV, SY, D, S, MB \\
\hline & Aerococcus viridans 2 & NR, SY & NR, PV, SY \\
\hline & Aerococcus viridans 1 & $\mathrm{D}, \mathrm{PV}, \mathrm{S}, \mathrm{MB}$ & 1 \\
\hline & Enterococcus avium & 1 & PV \\
\hline & Listeria sp. (rods) & NR & S \\
\hline & Leuconostoc sp. (coccobacilli) & MR, PV, SY & NR, MR, D, PV, MB \\
\hline & Streptococcus bovis 1 & PV & 1 \\
\hline & Gemella haemolysans & S & / \\
\hline & Gardnerella vaginalis (coccobacilli) & l & NR \\
\hline & Abiotrophia defective (coccobacilli) & S & l \\
\hline \multirow{7}{*}{ Dschang } & Streptococcus thermophilus & $\mathrm{P}, \mathrm{V}, \mathrm{G}$ & $P, G$ \\
\hline & Streptococcus acidomonimus & 1 & $\mathrm{P}$ \\
\hline & Aerococcus viridans 3 & $\mathrm{P}$ & l \\
\hline & Aerococcus viridans 1 & $\mathrm{~V}$ & l \\
\hline & Enterococcus durans & $\mathrm{P}$ & G \\
\hline & Leuconostoc sp. (coccobacilli) & $V, G$ & 1 \\
\hline & Listeria sp. (rods) & l & $\mathrm{P}$ \\
\hline \multirow{10}{*}{ Bafoussam } & Streptococcus thermophilus & $\mathrm{C}, \mathrm{K}$ & $\mathrm{C}, \mathrm{K}$ \\
\hline & Streptococcus acidomonimus & $\mathrm{T}, \mathrm{Ce}$ & $\mathrm{T}$ \\
\hline & Streptococcus uberis & 1 & $\mathrm{C}$ \\
\hline & Enterococcus durans & l & $\mathrm{C}$ \\
\hline & Lactococcus lactis subsp. lactis & l & $\mathrm{Ce}$ \\
\hline & Streptococcus canis & $\mathrm{K}$ & l \\
\hline & Aerococcus viridans 1 & $\mathrm{~T}$ & $\mathrm{C}$ \\
\hline & Aerococcus viridans 2 & / & $\mathrm{Ce}$ \\
\hline & Enterococcus durans & $\mathrm{C}$ & l \\
\hline & Enterococcus faecium & $\mathrm{C}$ & l \\
\hline \multirow{6}{*}{ Commercial } & Streptococcus thermophilus & AA & AA \\
\hline & Streptococcus constellatus & $\mathrm{BB}$ & $\mathrm{BB}$ \\
\hline & Lactococcus lactis subsp. lactis & / & $\mathrm{CC}$ \\
\hline & Enterococcus durans & AA & AA \\
\hline & Enterococcus faecium & $\mathrm{AA}$ & $\mathrm{AA}$ \\
\hline & Enterococcus avium & $\mathrm{CC}$ & $\mathrm{CC}$ \\
\hline
\end{tabular}

/: absence of lactic streptococci and other cocci.

occurrences in samples from Bamenda, Dschang, Bafoussam, and commercial, respectively (Table 4 ). It had a lower percentage of occurrences in samples from Bamenda during both seasons (Table 5). Leuconostoc sp. (coccobacilli) was the fourth with $11.11 \%$ of occurrence and absent in samples from Bafoussam and commercial brands (4). It represented $18.18 \%$ and $20.83 \%$ of isolates from Bamenda during the dry and rainy seasons, respectively, but only present during the dry season in some samples from Dschang (25\%). Lastly, Lactococcus lactis subsp. lactis was found in just two samples Ce (Bafoussam) and CC (commercial yoghurt) representing $2.22 \%$ of isolates (Table 4 ).

Apart from $S$. thermophilus which is used as a starter in the production of yoghurt as well as the production of fermented dairy products [40], the rest of the Streptococcus species (Streptococcus constellatus, Streptococcus canis, Streptococcus acidomonimus, Streptococcus uberis, and Streptococcus bovis), representing $8.88 \%$ of isolates, have been associated with infections in humans and even animals [41]. However, the abundance of $A$. viridans during the dry season may be attributed to the dusty environment during this period of the year since it is a saprophytic microorganism commonly found in the air of occupied places and in dust [42]. Enterococcus sp., found almost every in the environment when present in yoghurt, indicates neglect in sanitary control measures during production and is also implicated in food poisoning outbreaks [43-45]. They can even survive the unfavorable low $\mathrm{pH}$ environment of yoghurt [46]. Some strains have probiotic traits [47, 48] like E. faecium [49], whereas others (E. faecium, E. durans, and E. avium) are 


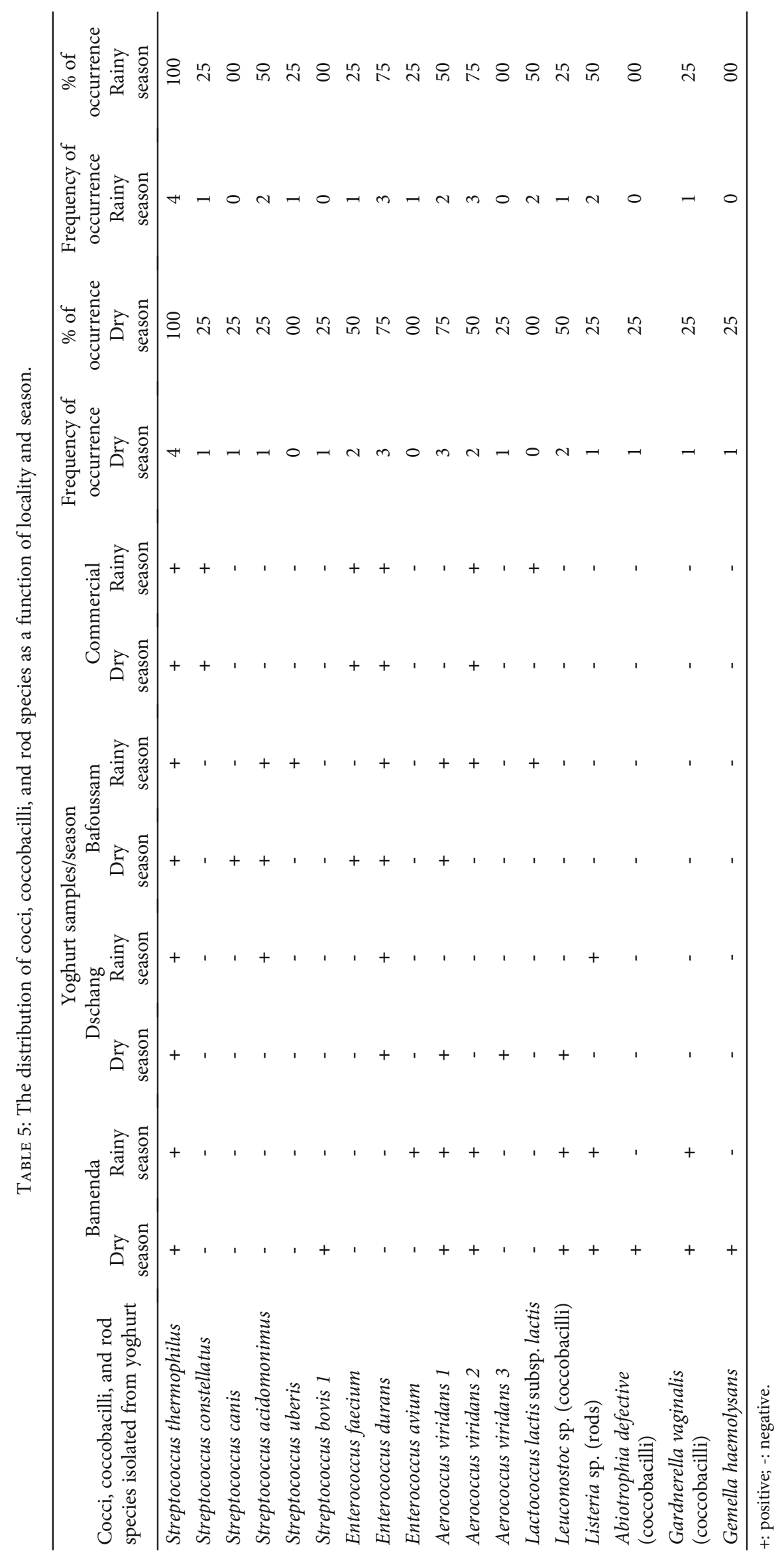


TABLE 6: The susceptibility of cocci, coccobacilli, and rod species to some conventional antibiotics.

\begin{tabular}{|c|c|c|c|c|c|c|c|c|c|}
\hline \multirow{2}{*}{ Coccus species } & \multirow{2}{*}{ Parameter } & \multicolumn{8}{|c|}{ Antibiotic } \\
\hline & & GEN & CIP & ERY & TET & NOR & AMP & STRE & CHL \\
\hline \multirow{2}{*}{ Gemella haemolysans } & MIC & $>256$ & $>128$ & $>256$ & $>256$ & $>256$ & $>256$ & $>256$ & $>128$ \\
\hline & $\mathrm{MBC}$ & ND & ND & ND & ND & ND & ND & ND & ND \\
\hline \multirow{2}{*}{ Gardnerella vaginalis (coccobacilli) } & MIC & $>256$ & $>128$ & $>256$ & $>256$ & $>256$ & $>256$ & $>256$ & $>128$ \\
\hline & $\mathrm{MBC}$ & ND & ND & ND & ND & ND & ND & ND & ND \\
\hline \multirow{2}{*}{ Streptococcus constellatus } & MIC & 16 & $<1$ & $>256$ & $<2$ & 16 & $>256$ & $>256$ & $>128$ \\
\hline & $\mathrm{MBC}$ & 64 & 2 & ND & $<2$ & 64 & ND & ND & ND \\
\hline \multirow{2}{*}{ Enterococcus faecium } & MIC & $>256$ & $>128$ & $>256$ & $>256$ & $>256$ & $>256$ & $>256$ & $>128$ \\
\hline & $\mathrm{MBC}$ & ND & ND & ND & ND & ND & ND & ND & $\mathrm{ND}$ \\
\hline \multirow{2}{*}{ Enterococcus avium } & MIC & $>256$ & $>128$ & $>256$ & $>256$ & $>256$ & $>256$ & $>256$ & $>128$ \\
\hline & $\mathrm{MBC}$ & ND & ND & ND & ND & ND & ND & ND & $\mathrm{ND}$ \\
\hline \multirow{2}{*}{ Streptococcus canis } & MIC & 32 & $<1$ & $>256$ & $>256$ & 8 & $<2$ & 256 & 4 \\
\hline & $\mathrm{MBC}$ & 256 & 2 & ND & ND & 128 & $<2$ & I & 8 \\
\hline \multirow{2}{*}{ Enterococcus durans } & MIC & $>256$ & $>128$ & $>256$ & $>256$ & $>256$ & $>256$ & $>256$ & $>128$ \\
\hline & $\mathrm{MBC}$ & ND & ND & ND & ND & ND & ND & ND & ND \\
\hline \multirow{2}{*}{ Streptococcus acidomonimus } & MIC & $<2$ & $<1$ & 128 & $<2$ & $<2$ & $>256$ & 4 & 32 \\
\hline & $\mathrm{MBC}$ & 128 & 128 & l & 64 & $<2$ & ND & 128 & l \\
\hline \multirow{2}{*}{ Lactococcus lactis subsp. lactis } & MIC & $<2$ & $<1$ & $<2$ & $<2$ & $<2$ & $<2$ & 32 & 4 \\
\hline & $\mathrm{MBC}$ & 8 & $<1$ & $<2$ & $<2$ & $<2$ & 16 & I & 32 \\
\hline \multirow{2}{*}{ Aerococcus viridans 1} & MIC & 256 & $>128$ & $>256$ & $>256$ & $>256$ & $>256$ & $>256$ & 32 \\
\hline & $\mathrm{MBC}$ & / & ND & ND & ND & ND & ND & ND & l \\
\hline \multirow{2}{*}{ Aerococcus viridans 2} & MIC & $<2$ & $<1$ & $<2$ & $<2$ & 32 & 8 & 64 & 32 \\
\hline & $\mathrm{MBC}$ & 8 & 8 & 64 & $<2$ & 128 & 32 & 256 & 64 \\
\hline \multirow{2}{*}{ Aerococcus viridans 3} & MIC & $>256$ & $>128$ & $>256$ & $>256$ & $>256$ & $>256$ & $>256$ & $>128$ \\
\hline & $\mathrm{MBC}$ & ND & ND & ND & ND & ND & ND & ND & ND \\
\hline \multirow{2}{*}{ Streptococcus uberis } & MIC & $>256$ & $>128$ & $>256$ & $>256$ & $>256$ & $>256$ & $>256$ & $>128$ \\
\hline & $\mathrm{MBC}$ & ND & ND & ND & ND & ND & ND & ND & ND \\
\hline \multirow{2}{*}{ Abiotrophia defectiva (coccobacilli) } & $\mathrm{MIC}$ & $>256$ & $>128$ & $>256$ & $>256$ & $>256$ & $>256$ & $>256$ & $>128$ \\
\hline & $\mathrm{MBC}$ & ND & ND & ND & ND & ND & ND & ND & ND \\
\hline \multirow{2}{*}{ Streptococcus bovis 1} & MIC & $>256$ & $>128$ & $>256$ & $>256$ & $>256$ & $>256$ & $>256$ & $>128$ \\
\hline & $\mathrm{MBC}$ & ND & ND & ND & ND & ND & ND & ND & ND \\
\hline \multirow{2}{*}{ Leuconostoc sp. (coccobacilli) } & MIC & $>256$ & $>128$ & $>256$ & $>256$ & $>256$ & $>256$ & $>256$ & $>128$ \\
\hline & $\mathrm{MBC}$ & ND & ND & ND & ND & ND & ND & ND & ND \\
\hline \multirow{2}{*}{ Listeria sp. (rod) } & $\mathrm{MIC}$ & $>256$ & $>128$ & $>256$ & $>256$ & $>256$ & $>256$ & $>256$ & $>128$ \\
\hline & $\mathrm{MBC}$ & ND & ND & ND & ND & ND & ND & ND & ND \\
\hline \multirow{2}{*}{ Streptococcus thermophilus (MB4 I) } & MIC & $<2$ & $<1$ & 128 & 8 & 8 & 32 & 16 & 4 \\
\hline & $\mathrm{MBC}$ & $<2$ & 4 & 256 & $>256$ & 16 & 64 & 64 & 64 \\
\hline \multirow{2}{*}{ Streptococcus thermophilus (C2 I) } & MIC & 8 & $<1$ & $<2$ & $<2$ & 16 & $<2$ & 32 & 4 \\
\hline & $\mathrm{MBC}$ & 8 & $<1$ & 16 & 32 & 32 & $<2$ & l & 16 \\
\hline
\end{tabular}

GEN: gentamycin; CIP: ciprofloxacin; ERY: erythromycin; TET: tetracycline; NOR: norfloxacin; AMP: ampicillin; STRE: streptomycin; CHL: chloramphenicol; /: no data; ND: not determined.

the causative agents for serious infections in humans [50,51]. Leuconostoc sp. (coccobacilli), a heterofermentative LAB, is involved in a large number of spontaneous fermentations of food products and contributes to the nonstarter lactic acid bacteria (NSLAB) populations of dairy environments [52] with antimicrobial action against microorganisms [53]. More so, Lc. lactis subsp. lactis present in just two samples Ce (artisanal from Bafoussam) and CC (commercial yoghurt) has also been used on a large scale in food industries for the man- ufacture of various fermented dairy products such as sour milk [54]. Since the two samples (Ce and CC) were void of L. bulgaricus and S. thermophilus, it might be concluded that these producers (CC and $\mathrm{Ce}$ ) intentionally used it to acidify their fermented products. The rest of the cocci (Gemella haemolysans), rods (Listeria sp.), and coccobacilli (Abiotrophia defectiva and Gardnerella vaginalis) which were also isolated from some of the artisanal yoghurt samples have been known to be pathogenic to man and even animals $[55,56]$. 
TABLE 7: The susceptibility of lactobacillus species to some conventional antibiotics.

\begin{tabular}{|c|c|c|c|c|c|c|c|c|c|}
\hline \multirow{2}{*}{ Lactobacillus species } & \multirow{2}{*}{ Parameter } & \multicolumn{8}{|c|}{ Antibiotic } \\
\hline & & GEN & CIP & ERY & TET & NOR & AMP & STRE & CHL \\
\hline \multirow{2}{*}{ Lactobacillus bulgaricus (SY5 I) } & MIC & $<2$ & $<1$ & $<2$ & $<2$ & $<2$ & $<2$ & 16 & 2 \\
\hline & $\mathrm{MBC}$ & $<2$ & $<1$ & $<2$ & $<2$ & 64 & $<2$ & 64 & 2 \\
\hline \multirow{2}{*}{ Lactobacillus viridescens (D5 II) } & MIC & 4 & 2 & 4 & $<2$ & 16 & $<2$ & 16 & 2 \\
\hline & $\mathrm{MBC}$ & 4 & 2 & 8 & $<2$ & 16 & $<2$ & 32 & 8 \\
\hline \multirow{2}{*}{ Lactobacillus bulgaricus (NR4 II) } & MIC & 8 & $<1$ & $<2$ & $<2$ & 16 & $<2$ & 64 & 8 \\
\hline & $\mathrm{MBC}$ & 16 & 2 & $<2$ & $<2$ & 32 & $<2$ & 128 & 16 \\
\hline \multirow{2}{*}{ Lactobacillus viridescens (V4 II) } & MIC & $<2$ & $<1$ & $<2$ & $<2$ & 16 & $<2$ & 32 & $<1$ \\
\hline & $\mathrm{MBC}$ & $<2$ & $<1$ & 64 & $<2$ & 32 & 64 & 64 & 64 \\
\hline \multirow{2}{*}{ Lactobacillus fermentum (Ce1 II) } & MIC & 4 & $<1$ & $<2$ & $<2$ & 8 & $<2$ & 8 & $<1$ \\
\hline & $\mathrm{MBC}$ & 4 & 2 & $<2$ & $<2$ & 16 & $<2$ & 32 & 4 \\
\hline \multirow{2}{*}{ Lactobacillus fermentum (C3 II) } & MIC & $>256$ & $>128$ & $>256$ & $>256$ & $>256$ & $>256$ & $>256$ & $>128$ \\
\hline & MBC & ND & ND & ND & ND & ND & ND & $\mathrm{ND}$ & ND \\
\hline \multirow{2}{*}{ Lactobacillus cellobiosus (CC6 III) } & MIC & 4 & 2 & $<2$ & $<2$ & 16 & $<2$ & 32 & 4 \\
\hline & $\mathrm{MBC}$ & 4 & 2 & $<2$ & $<2$ & 16 & 4 & 32 & 4 \\
\hline \multirow{2}{*}{ Lactobacillus cellobiosus (CC7 III) } & MIC & $<2$ & $<1$ & $<2$ & $<2$ & 16 & $<2$ & $<2$ & $<1$ \\
\hline & $\mathrm{MBC}$ & 4 & $<1$ & $<2$ & 4 & 16 & $<2$ & 8 & 8 \\
\hline \multirow{2}{*}{ Lactobacillus lactis (AA5 II) } & MIC & 4 & $<1$ & $<2$ & $<2$ & 32 & $<2$ & 32 & 2 \\
\hline & $\mathrm{MBC}$ & 8 & 2 & $<2$ & $<2$ & 32 & $<2$ & 32 & 2 \\
\hline \multirow{2}{*}{ Lactobacillus bulgaricus (AA1 II) } & MIC & 4 & $<1$ & $<2$ & $<2$ & 16 & $<2$ & 16 & 2 \\
\hline & $\mathrm{MBC}$ & 4 & $<1$ & $<2$ & $<2$ & 16 & $<2$ & 32 & 8 \\
\hline \multirow{2}{*}{ Lactobacillus bulgaricus (MB5 II) } & MIC & $<2$ & $<1$ & $<2$ & $<2$ & 16 & $<2$ & 32 & 4 \\
\hline & $\mathrm{MBC}$ & 4 & 2 & $<2$ & $<2$ & 32 & $<2$ & 64 & 8 \\
\hline \multirow{2}{*}{ Lactobacillus bulgaricus (PV8 I) } & MIC & 4 & $<1$ & $<2$ & $<2$ & 16 & $<2$ & 16 & 4 \\
\hline & $\mathrm{MBC}$ & 4 & 8 & 8 & $<2$ & 32 & $<2$ & 32 & 16 \\
\hline \multirow{2}{*}{ Lactobacillus bulgaricus (T2 I) } & $\mathrm{MIC}$ & 4 & 2 & $<2$ & $<2$ & 16 & $<2$ & 32 & 2 \\
\hline & $\mathrm{MBC}$ & 8 & 8 & $<2$ & 8 & 32 & $<2$ & 64 & 8 \\
\hline \multirow{2}{*}{ Lactobacillus bulgaricus (D1 II) } & MIC & 8 & $<1$ & $<2$ & $<2$ & 16 & $<2$ & 32 & 8 \\
\hline & $\mathrm{MBC}$ & 8 & 2 & $<2$ & $<2$ & 32 & $<2$ & 128 & 128 \\
\hline \multirow{2}{*}{ Lactobacillus bulgaricus (S2 I) } & MIC & 4 & $<1$ & $<2$ & $<2$ & 16 & $<2$ & 32 & 4 \\
\hline & $\mathrm{MBC}$ & 8 & 4 & 4 & $<2$ & 32 & $<2$ & 64 & 16 \\
\hline
\end{tabular}

GEN: gentamycin; CIP: ciprofloxacin; ERY: erythromycin; TET: tetracycline; NOR: norfloxacin; AMP: ampicillin; STRE: streptomycin; CHL: chloramphenicol; ND: not determined.

\subsection{Susceptibility of Lactic Acid Bacteria Isolates to Conventional Drugs}

3.3.1. Susceptibility of Cocci, Coccobacilli, and Rod Isolates to Some Conventional Antibiotics. The minimal inhibitory concentration (MIC) is the lowest antibiotic concentration that inhibits visible bacterial growth after overnight incubation [57]. It is considered that when MICs are $\geq 8 \mu \mathrm{g} / \mathrm{ml}$, the bacteria may be considered as "moderately resistant"; when MICs are above $32 \mu \mathrm{g} / \mathrm{ml}$, it may be classified as "clinically resistant" to the antibiotic [58]. Based on this scale, $53.33 \%$ $(8 / 15)$ of the coccus isolates were clinically resistant to all the tested antibiotics and $26.67 \%(4 / 15)$ were resistant to at least 4 antibiotics, while only $20 \%(3 / 15)$ were sensitive to most of the antibiotics. More so, $100 \%$ of coccobacilli (3/3) and rods $(1 / 1)$ were clinically resistant to all the antibiotics used (Table 6).
The profiles of antimicrobial susceptibility of LAB have been documented in many countries $[59,60]$. Most of the Streptococcus sp. were sensitive to a majority of the antibiotics. This was in line with the works of other researchers who stated that most members of the Streptococcus sp. are susceptible to the beta-lactams, macrolides, and chloramphenicol $[61,62]$. Only the MBC values of $36.84 \%$ of isolates were determined (Table 6). The ratio $\mathrm{MBC} / \mathrm{MIC}$ was generally below 4, indicating that these conventional antibiotics exerted bactericidal effects [63] except Streptococcus constellatus whose $\mathrm{MBC} / \mathrm{MIC}$ ratio was above 4 in most cases hence bacteriostatic. Most Aerococcus sp. were resistant and this corroborated other results that they are resistant to chloramphenicol, quinolones, ampicillin, and gentamicin [64]. It has also been reported that Leuconostoc sp. (coccobacilli) are usually resistant to gentamycin and streptomycin while most species are sensitive to chloramphenicol, erythromycin, and 
tetracycline [60]. In this study, the species was resistant to all the antibiotics used. The enterococcus species (13.33\%) being the third abundant coccus isolate obtained in this study are controversial species that should not be used for probiotic applications, because of its notable resistance to some of the widely used antibiotics. Moreover, they are known to be resistant to most antibiotics including aminoglycosides, macrolides, chloramphenicol, tetracyclines, and quinolones [65]. Recent studies have focused on enterococci due to their increasing antibiotic resistance [66] although some members of this genus have been known to possess health-promoting effects and technological properties [67]. In addition, this genus can transfer the antibiotic resistant-encoding gene to pathogens, for example, between enterococci and staphylococci [68], spreading antibiotic resistance into the environment and food chains $[65,69]$, which is a serious public health problem. The rest of the cocci (Gemella haemolysans), rods (Listeria sp.), and coccobacilli (Abiotrophia defectiva and Gardnerella vaginalis) which have been known to be pathogenic to man and even animals were highly resistant to all antibiotics used. This can be very dangerous since they may cause infections in humans that are difficult to be treated.

3.3.2. Susceptibility of Lactobacillus Isolates to Some Conventional Antibiotics. Unlike the cocci, the lactobacilli were generally very sensitive to the conventional antibiotics except L. fermentum (C3 II), which was resistant to all the antibiotics at the tested concentration (Table 7). However, $91.67 \%(14 / 15)$ of isolates were resistant to norfloxacin and streptomycin but sensitive to ciprofloxacin, erythromycin, tetracycline, and ampicillin while only $20.00 \%$ (3/15) were resistant to gentamycin and chloramphenicol. Generally, $93.33 \%(14 / 15)$ of the isolates were very sensitive while only $6.67 \%$ (L. fermentum) were resistant (Table 7). The MBC values were also obtained, and the $\mathrm{MBC} / \mathrm{MIC}$ ratio was generally below 4 as in the case of cocci, meaning that the conventional antibiotics exerted a bactericidal effect on the lactobacilli. Furthermore, the high sensitivity of lactobacilli to antibiotics is in line with results of other works, which stated that they are generally sensitive to inhibitors of protein synthesis such as chloramphenicol, erythromycin, and tetracycline as well as $\beta$-lactamase inhibitors (ampicillin) [70, 71]. However, lactobacilli have been known to be intrinsically resistant to aminoglycosides and fluoroquinolones [72]. This explains the $100 \%$ resistance observed with norfloxacin and streptomycin.

\section{Conclusion}

These results suggest that yoghurt production is best during the dry season because of appropriate environmental temperatures and high consumption. The paucity of the appropriate $\mathrm{LAB}$ and presence of pathogenic LAB caused by the absence of quality control and ignorance might hinder the health benefits and protection, which the food should provide to the consumers, thereby exposing them to high risk of food borne infection and intoxication coupled to the resistant isolates. The relatively high level of resistance (especially the cocci) to antimicrobial agents constitutes a major threat to public health as it may spread bacterial resistance among the populace who come in contact with these yoghurts. Moreover, the sensitivity of lactobacilli to these antibiotics suggests that yoghurt should be avoided during antibiotic treatment.

\section{Data Availability}

The data used to support the findings of this study are included within the article.

\section{Conflicts of Interest}

The authors declare that there is no conflict of interest regarding the publication of this article.

\section{References}

[1] ANOR, "Standard and quality agency standard for yoghurt and sweetened yoghurt, Cameroonian standards," vol. 127, pp. 2002-2004, 2002.

[2] C. Alimentarius, "CODEX standard for fermented milks 2432003," 6-16, 2003.

[3] M. E. Stiles and W. H. Holzapfel, "Lactic acid bacteria of foods and their current taxonomy," International Journal of Food Microbiology, vol. 36, no. 1, pp. 1-29, 1997.

[4] W. H. Holzapfel, P. Haberer, R. Geisen, J. Bjorkroth, and U. Schillinger, "Taxonomy and important features of probiotic microorganisms in food and nutrition," American Journal of Clinical Nutrition, vol. 73, pp. 365-373, 2001.

[5] L. Axelsson, "Lactic Acid Bacteria: Classification and Physiology," in Lactic Acid Bacteria. Microbiological and Functional Aspects, S. Salminen, A. Wright, and A. Ouwehand, Eds., pp. 1-66, Marcel Dekker Inc, New York, 2004.

[6] EFSA, "European Food Safety Authority. Opinion of the Scientific Committee on a request from EFSA related to a generic approach to the safety assessment by EFSA of microorganisms used in food/feed and the production of food/feed additives," The European Food Safety Authority Journal, vol. 226, pp. 116, 2005.

[7] J. Schrezenmeir and M. de Vrese, "Probiotics, prebiotics, and synbiotics - approaching a definition," American Journal of Clinical Nutrition, vol. 73, pp. 361-364, 2001.

[8] R. Martín, S. Langa, C. Reviriego et al., "Human milk is a source of lactic acid bacteria for the infant gut," Journal of Pediatrics, vol. 143, no. 6, pp. 754-758, 2003.

[9] J. Maciel, M. A. Teixeira, C. A. Moraes, and L. A. M. Gomide, "Antibacterial activity of lactic acid cultures isolated from Italian salami," Brazilian Journal of Microbiology, vol. 34, no. 1, pp. 121-122, 2003.

[10] M. Bachrouri, E. J. Quinto, and M. T. Mora, "Kinetic parameters of Escherichia coli O157:H7 survival during fermentation of milk and refrigeration of home-made yoghurt," International Dairy Journal, vol. 16, no. 5, pp. 474-481, 2006.

[11] I. Hussain, A. Rahman, and N. Atkinson, "Quality comparison of probiotic and natural yoghurt," Pakistan Journal of Nutrition, vol. 8, no. 1, pp. 9-12, 2009.

[12] S. Aslam and Q. Javed, "Isolation of acidophilic lactic acid bacteria antagonistic to microbial contaminants," Pakistan Journal of Zoology, vol. 42, pp. 567-573, 2010. 
[13] L. G. Moh, L. P. Keilah, P. T. Etienne, and K. Jules-Roger, "Seasonal microbial conditions of locally made yoghurt (shalom) marketed in some regions of Cameroon," International Journal of Food Science, vol. 2017, Article ID 5839278, 16 pages, 2017.

[14] G. M. Lamye, K. A. L. Suffo, T. E. Pamo, and J.-R. Kuiate, "Physical and chemical quality appraisal of locally made yoghurt marketed in some regions of Cameroon," World Journal of Food Science and Technology, vol. 1, no. 2, pp. 84-92, 2017.

[15] E. E. Álvarez-León, B. Román-Viñas, and L. Serra-Majem, "Dairy products and health: a review of the epidemiological evidence," British Journal of Nutrition, vol. 96, no. S1, pp. S94-S99, 2006.

[16] O. Cueva and K. J. Aryana, "Quality attributes of a heart healthy yogurt," LWT - Food Science and Technology, vol. 41, no. 3, pp. 537-544, 2008.

[17] WHO, World Health Organization, Global Strategy for the Containment of Antimicrobial Resistance, Taylor and Francis e-Library, Geneva, 2001.

[18] EC, "European Commission, Opinion of the scientific panel on additives and products or substances used in animal feed on the updating of the criteria used in the assessment of bacteria for resistance to antibiotics of human or veterinary importance," The European Food Safety Authority Journal, vol. 223, pp. 1-12, 2005.

[19] C. Fadela, C. Abderrahim, and B. Ahmed, "Sensory and physicochemical characteristic of yoghurt manufactured with Ewes and skim milk," World Journal of dairy and Food Science, vol. 4, no. 2, pp. 136-140, 2009.

[20] H. M. H. Mohammed, A. O. O. Osman, and E. M. Z. Ibtisam, "Assessment of chemical and microbiological quality of stirred yoghurt in Khartoum State," Research Journal of Animal and Veterinary Sciences, vol. 2, pp. 56-60, 2007.

[21] B. Igbabul, J. Shember, and J. Amove, "Physicochemical, microbiological and sensory evaluation of yoghurt sold in Makurdi metropolis," African Journal of Food Science and Technology, vol. 5, no. 6, pp. 129-135, 2014.

[22] M. A. Pereira, D. M. Almeida, and Sauer, "Avaliação da concentração de bactérias láticas viáveis em iogurtes com polpas de frutas," in Série em Ciência e Tecnologia de Alimentos: Desenvolvimento em Tecnologia de Alimentos, G. Santos Júnior and D. M. Almeida, Eds., pp. 7-13, UTFPR, Ponta Grossa, 2007.

[23] J. Okpalugo, K. Ibrahim, K. Izebe, and U. Inyang, "Aspects of microbial quality of some milk products in Abuja Nigeria," Tropical Journal of Pharmaceutical Research, vol. 7, no. 4, p. 1169, 2008.

[24] T. Masud, K. Sultana, and M. A. Shah, "Incidence of lactic acid bacteria isolated from indigenous dahi," Asian-Australasian Journal of Animal Sciences, vol. 4, no. 4, pp. 329-331, 1991.

[25] P. Aswal, A. Shukla, and S. Priyadarshi, "Yoghurt: preparation, characteristics and recent advancements," CIB Journal of BioProtocols, vol. 1, no. 2, pp. 2319-3840, 2012.

[26] R. T. Marshall, Standard Methods for Examination of Dairy Products, Public Health Assoc. Inc, Washington DC, 16th edition, 1992.

[27] APHA, American Public Health Association. Standards Methods for Examination of Dairy Products, American Public Health Association, Washington DC, USA, 17th edition, 2004.
[28] S. F. Torriani, F. Gardini, M. E. Guerzoni, and F. Dellaglio, "Use of response surface methodology to evaluate some variable affecting the growth and acidefication characteristics of yoghurt cultures," International Dairy Journal, vol. 6, no. 6, pp. 625-636, 1996.

[29] N. Tharmaraji and N. P. Shah, "Selective enumeration of Lactobacillus bulgaricus, Streptococcus thermophilus, Bifidobacteria, Lactobacillus casei and Propionibacteria," Journal of Dairy Science, vol. 86, no. 7, pp. 2288-2296, 2003.

[30] P. Gerhartdt, R. G. E. Murray, R. N. Costilon et al., Manual of Methods for General Bacteriology, American Society for Microbiology, Washington, DC., USA, 1981.

[31] J. N. Eloff, "A sensitive and quick microplate method to determine the minimal inhibitory concentration of plant extracts for bacteria," Planta Medica, vol. 64, no. 8, pp. 711-713, 1998.

[32] S. P. N. Mativandlela, N. Lall, and J. J. M. Meyer, “Antibacterial, antifungal and antitubercular activity of (the roots of) Pelargonium reniforme (CURT) and Pelargonium sidoides (DC) (Geraniaceae) root extracts," South African Journal of Botany, vol. 72, no. 2, pp. 232-237, 2006.

[33] V. Kuete, J. D. Wansi, A. T. Mbaveng, M. M. Kana Sop, A. T. Tadjong, and V. P. Beng, "Antimicrobial activity of the methanolic extract and compounds from Teclea afzelii (Rutaceae)," South African Journal of Botany, vol. 74, no. 4, pp. 572-576, 2008.

[34] V. Kuete, G. F. Wabo, B. Ngameni et al., "Antimicrobial activity of the methanolic extract, fractions and compounds from the stem bark of Irvingia gabonensis (Ixonanthaceae)," Journal of Ethnopharmacology, vol. 114, no. 1, pp. 54-60, 2007.

[35] A. Y. Tamine and R. K. Robinson, Yoghurt: Science and Technology, Cambridge, Woodhead Publishing Limited, 3rd edition, 2007.

[36] O. Kandler and N. Weiss, "Regular, Nonsporing Gram- Positive Rods," in Bergey's Manual of Systematic Bacteriology, P. Sneath, N. Mair, M. Sharpe, and J. Holt, Eds., vol. 2, no. 14, pp. 1208-1234, Williams \& Wilkins, Baltimore, MD, 1986.

[37] E. Blickstad, S. O. Enfors, and G. Molin, "Effect of hyperbaric carbon dioxide pressure on the microbial flora of pork stored at 4 or $14{ }^{\circ} \mathrm{C}$," Journal of Applied Bacteriology, vol. 50, no. 3, pp. 493-504, 1981.

[38] E. Blickstad and G. Molin, "The microbial flora of smoked pork loin and frankfurter sausage stored in different gas atmospheres at $4^{\circ} \mathrm{C}$," Journal of Applied Bacteriology, vol. 54, no. 1, pp. $45-56,1983$.

[39] J. M. Jay, Modern Food Microbiology, Van Nostrand Reinhold Company, New York, 2nd edition, 1978.

[40] R. Iyer, S. K. Tomar, T. U. Maheswari, and R. Singh, "Streptococcus thermophilus strains: multifunctional lactic acid bacteria," International Dairy Journal, vol. 20, no. 3, pp. 133-141, 2010.

[41] L. A. Cone, S. Etebar, and R. B. Waterbor, "Brain abscess due to Streptococcus acidominimus: first case report," Surgical Neurology, vol. 67, no. 3, pp. 296-297, 2007.

[42] G. A. Popescu, E. Benea, E. Mitache, C. Piper, and D. Horstkotte, "An unusual bacterium, Aerococcus viridans, and four cases of infective endocarditis," Journal of Heart Valve Diseases, vol. 14, pp. 317-319, 2005.

[43] S. Koch, M. Hufnagel, C. Theilacker, and J. Huebner, "Enterococcal infections: host response, therapeutic, and prophylactic possibilities," Vaccine, vol. 22, no. 7, pp. 822-830, 2004. 
[44] A. Bhardwaj, R. K. Malik, and P. Chauhan, "Functional and safety aspects of enterococci in dairy foods," Indian Journal of Microbiology, vol. 48, no. 3, pp. 317-325, 2008.

[45] A. Yabaya and A. Idris, "Bacteriological quality assessment of some yoghurt brands sold in Kaduna metropolis Jorind," Alexandria Journal of Veterinary Sciences, vol. 10, no. 2, pp. 35-39, 2012.

[46] L. M. El-Malt, A. H. Karima, and M. Ahmed, "Microbiological evaluation of yoghurt products in Qena city, Egypt," Veterinary World, vol. 6, no. 7, pp. 400-404, 2013.

[47] J. Cleveland, T. J. Montville, I. F. Nes, and M. L. Chikinda, "Bacteriocins: safe, natural antimicrobials for food preservation," International Journal of Food Microbiology, vol. 71, p. 120, 2001.

[48] HPA, "Health Protection Agency, Enterococcus sp. and Glycopeptide-Resistant Enterococci (GRE)," 2005 http:// www.hpa.org.uk.

[49] Z. Erginkaya, N. E. Yurdakul, and A. Karakas, “The properties of Enterococcus faecium and Enterococcus faecalis as a starter and probiotic cultures," Journal of Food, vol. 32, no. 3, pp. 137$142,2007$.

[50] S. Mohanty, B. Dhawan, A. Kapil, B. K. Das, P. Pandey, and A. Gupta, "Brain abscess due to Enterococcus avium," The American Journal of the Medical Sciences, vol. 329, no. 3, pp. 161-162, 2005.

[51] K. Shea, E. Hilburger, A. Baroco, and E. Oldfield, "Successful treatment of vancomycin-resistant Enterococcus faecium pyelonephritis with daptomycin during pregnancy," Annals of Pharmacotherapy, vol. 42, no. 5, pp. 722-725, 2008.

[52] T. R. Klaenhammer, R. Barrangou, B. L. Buck, M. A. AzcaratePeril, and E. Altermann, "Genomic features of lactic acid bacteria effecting bioprocessing and health," FEMS Microbiology Reviews, vol. 29, no. 3, pp. 393-409, 2005.

[53] S. Ennahar, T. Sashihara, K. Sonomoto, and A. Ishizaki, "Class IIa bacteriocins: biosynthesis, structure, and activity," Microbiology Reviews, vol. 24, no. 1, pp. 85-106, 2000.

[54] J. Prodelalova, A. Spanova, and B. Rittich, "Application of PCR, rep-PCR and RAPD techniques for typing of Lactococcus lactis strains," Folia Microbiologica, vol. 50, no. 2, pp. 150-154, 2005.

[55] R. Khan, C. Urban, D. Rubin, and S. Segal-Maurer, "Subacute endocarditis caused by Gemella haemolysans and a review of the literature," Scandinavian Journal of Infectious Diseases, vol. 36, no. 11-12, pp. 885-888, 2009.

[56] V. Goulet, C. Hedberg, A. Le Monnier, and H. De Valk, "Increasing incidence of Listeriosis in France and other European countries," Emerging Infectious Diseases, vol. 14, no. 5, pp. 734-740, 2008.

[57] I. Phillips, J. M. Andrews, E. Bridson et al., A Guide to Sensitivity Testing. Report of the Working Party on Antibiotic Sensitivity Testing of the British Society for Antimicrobial Chemotherapy, 1991.

[58] C. Walsh, Natural and Producer Immunity versus Acquired Resistance, ASM press (Ed.), antibiotics: actions, origins, resistance, Washington, 2003.

[59] S. Kastner, V. Perreten, H. Bleuler, G. Hugenschmidt, C. Lacroix, and L. Meile, "Antibiotic susceptibility patterns and resistance genes of starter cultures and probiotic bacteria used in food," Systematic and Applied Microbiology, vol. 29, no. 2, pp. 145-155, 2006.

[60] A. K. Katla, H. Kruse, G. Johnsen, and H. Herikstad, “Antimicrobial susceptibility of starter culture bacteria used in Norwe- gian dairy products," International Journal of Food Microbiology, vol. 67, no. 1-2, pp. 147-152, 2001.

[61] A. Limia, K. L. Jiménez, T. Alarcon, and M. Lopez-Brea, "Fiveyear analysis of antimicrobial susceptibility of the Streptococcus milleri group," European Journal of Clinical Microbiology and Infectious Diseases, vol. 18, no. 6, pp. 440-444, 1999.

[62] CLSI, Clinical and Laboratory Standards Institute, 17th Informational Supplement, Performance Standards for Susceptibility Testing, MS 100-S17. Wayne, 2007.

[63] A. T. Mbaveng, B. Ngameni, V. Kuete et al., "Antimicrobial activity of the crude extracts and five flavonoids from the twigs of_Dorstenia barteri_(Moraceae)," Journal of Ethnopharmacology, vol. 116, no. 3, pp. 483-489, 2008.

[64] A. Gopalachar, R. L. Akins, W. R. Davis, and A. A. Siddiqui, "Urinary tract infection caused by Aerococcus viridans, a case report," Medical Science Monitor, vol. 10, pp. 73-75, 2004.

[65] I. Klare, C. Konstabel, D. Badstubner, G. Werner, and W. Witte, "Occurrence and spread of antibiotic resistances in Enteroccoccus faecium," International Journal of Food Microbiology, vol. 88, no. 2-3, pp. 269-290, 2003.

[66] S. Bhardwaj, Therapeutic implications of molecular signal in relation to $\beta$-lactum stress in Enterococci [Ph.D. thesis], Barkatullah University, Bhipal, MP, India, 2006.

[67] G. Giraffa, "Functionality of enterococci in dairy products," International Journal of Food Microbiology, vol. 88, no. 2-3, pp. 215-222, 2003.

[68] F. C. Tenover and L. C. McDonald, "Vancomycin-resistant staphylococci and enterococci: epidemiology and control," Current Opinion in Infectious Diseases, vol. 18, no. 4, pp. 300-305, 2005.

[69] H. Abriouel, R. Lucas, N. B. Omar et al., "Enterocin AS-48RJ: a variant of enterocin AS-48 chromosomally encoded by Enterococcus faecium RJ16 isolated from food," Systematic and Applied Microbiology, vol. 28, pp. 387-397, 2005.

[70] M. Danielsen and A. Wind, "Susceptibility of Lactobacillus sp. to antimicrobial agents," International Journal of Food Microbiology, vol. 82, no. 1, pp. 1-11, 2003.

[71] R. Coppola, M. Succi, P. Tremonte, A. Reale, G. Salzano, and E. Sorrentino, "Antibiotic susceptibility of Lactobacillus rhamnosus strains isolated from Parmigiano Reggiano cheese," Le Lait, vol. 85, no. 3, pp. 193-204, 2005.

[72] M. R. D'Aimmo, M. Modesto, and B. Biavati, “Antibiotic resistance of lactic acid bacteria and Bifidobacterium spp. isolated from dairy and pharmaceutical products," International Journal of Food Microbiology, vol. 115, no. 1, pp. 35-42, 2007. 